\title{
Hauptmann's The Weavers as "Social Sculpture" Margaret Sutherland
}

Gerhart Hauptmann (1862-1946) was one of Germany's bestknown and most prolific writers during the latter part of the nineteenth and first half of the twentieth century. The colossal impact of his dramas, prose works, essays and other writing is reflected in the many honorary doctorates, and countless awards that he received throughout his life, including the Nobel Prize for Literature in 1912. "Thomas Mann's words on the occasion of Hauptmann's 70 ${ }^{\text {th }}$ birthday in 1932 give some insight into his work:

He did not speak in his own guise, but let life itself talk with the tongues of changing, active human beings. He was neither a man of letters nor a rhetorician, neither an analyst nor a formal dialectician; his dialectic was that of life itself; it was human drama. ${ }^{2}$

It is not surprising that Hauptmann was not a man of letters, given that his family was not considered to be particularly literary and he himself was not very academically inclined at school. His mother even encouraged him to pursue a career in gardening! ${ }^{3}$ It was as a schoolboy, however, that he first came into contact with the theatre. Warren Maurer reports that he had been intrigued by the spa theatre in his home town and had played with a cardboard Hamlet and stage as a small child. His first direct theatrical experience was said to be at the Breslau Theatre where he saw the famous Meininger troupe's productions of such dramas as

1 This was awarded primarily for The Weavers. (See Peter Sprengel, Gerhart Hauptmann. Epoche - Werk - Wirkung [München: C. H. Beck, 1984], 97.) In 1920 there was even talk of his being put forward as a candidate for president of the Reich (Gerhard Schildberg-Schroth, Gerhart Hauptmann: Die Weber [Münster: LIT Verlag, 2004], 51.) His failure to leave Germany or to speak out during the Nazi period led to a tarnished image after the fall of the Third Reich.

2 Horst Frenz in his introduction to Gerhart Hauptmann, Three Plays: The Weavers. Hannele. The Beaver Coat, trans. Horst Frenz and Miles Waggoner (Prospect Heights: Waveland Press, 1977), v.

${ }^{3}$ Warren R. Maurer, Understanding Gerhart Hauptmann (Columbia: University of South Carolina Press, 1992), 6. 
Macbeth, Julius Caesar, Schiller's Wallenstein trilogy and Wilhelm Tell, and Kleist's Hermannsschlacht (The Battle of Hermann). ${ }^{4}$ When he turned his hand to writing, he proved so successful that he had already published five dramas and come to public attention by the time he had completed The Weavers in 1892 at the age of $30 .^{5}$ And he was not only an unusually prolific dramatist, but also highly ambitious in his endeavour to devise a new type of drama:

I look upon the old forms of drama as so many worn out instruments. I can invent a new and finer instrument for myself than the French dramatists could give me. Why should I read their plays? What we need is to get away from the old conventions to something truer, finer and more subtle. Our plays have grown conventional. ${ }^{6}$

Hauptmann's endeavour proved enormously successful, with the dramatic form of The Weavers being hailed as revolutionary by his contemporaries. Yet writing had not been his first career choice. After a short stint as an agricultural apprentice, he enrolled in October 1880 in the sculpture class (Bildhauerklasse) at the Royal Art and Vocational School (Königliche Kunst- und Gewerbeschule) in Breslau, and his eyes were set on a career as a sculptor for almost four years. In November 1882 he moved to the University of Jena, where he remained for one semester, leaving in March 1883 for the Mediterranean where he lived until March 1884 and tried to work for some of that time in Rome as a sculptor. ${ }^{7}$ That attempt proved unsuccessful for reasons we do not know much about, although it is probably safe to assume that they

${ }^{4}$ Ibid., 7.

${ }^{5}$ His other four dramas before that time were Before Sunrise, The Feast of the Reconciliation, Lonely Lives and Colleague Crampton.

${ }^{6}$ From an interview with Charles Henry Meltzer, "Hauptmann, Naturalist: The German Author, Poet and Playwright talks of his Ideals and his Realizations," The New York World, 18 February 1894. Taken from Gerhart Hauptmann, Tagebuch 1892 bis 1894, ed. Martin Machatzke (Frankfurt am Main, Berlin, Wien: Propyläen, 1985), 128-29.

7 Franz-Josef Payrhuber, Gerhart Hauptmann (Stuttgart: Reclam Verlag, 1998), $15-16$. 
involved the practical aspects of carving. ${ }^{8}$ This appears even more likely if one looks at the way carving was practised by a sculptor whom he admired and visited in Florence, Adolf von Hildebrand: ${ }^{9}$ while other sculptors, after completing their plaster model, traditionally left the carving of the marble to specialised practitioners, von Hildebrand was the first sculptor in the nineteenth century involved with the carving of his marble sculptures from beginning to end. ${ }^{10}$ Given that Hauptmann's ambition to become a sculptor had been genuine, it is tempting to speculate where he could have ended up in that profession under more auspicious circumstances. However, avoiding any such speculation, this essay will only consider to what extent a sculptor's point of view, free from a lack of practical talent, can explain some of the strikingly new features in Hauptmann's The Weavers (to which he gave the subtitle these days normally translated in English as A Play of the Eighteen-Forties-the complete original German title is Die Weber. Ein Schauspiel aus den vierziger Jahren). ${ }^{11}$

In keeping with his Naturalist philosophy, in The Weavers Hauptmann presents a slice of life in the Silesian towns of Peterswaldau, Kaschbach and Langenbielau. It is, however, not an arbitrarily chosen slice, because it focuses on an event of momentous significance for this community. What initially seems to be a straightforward drama, is in fact an extremely complex one, reflecting the complexities of the community it portrays. Using an almost kaleidoscopic technique, Hauptmann allows us to view the incipient revolution from several different angles and in several different ways. There is no strictly delineated exposition, for example, but what would usually be considered as expositionary elements are introduced right up until the final act, so that

${ }^{8}$ His plans as a sculptor came to an end in 1884 with the collapse of a huge statue of a Germanic warrior. See Rüdiger Bernhardt, Gerhart Hauptmann: Eine Biografie (Fischerhude:Verlag Atelier im Bauernhaus, 2007), 41.

9 Wolfgang Leppmann, Gerhart Hauptmann: Leben, Werk und Zeit (Bern, München, Wien: Scherz Verlag, 1986), 198.

${ }^{10}$ Angela Hass, Adolf von Hildebrand: Das plastische Portrait (München: Prestel, 1984), cat. no. 27, 76. Having become a playwright, Hauptmann almost completely gave up producing sculptures.

11 All quotations are taken from Gerhart Hauptmann, The Weavers, trans. Frank Marcus (London: Methuen, 1980). 
information is gradually filled in and earlier questions answered. Some of this information may be highly significant, such as the almost chance mention in acts 4 and 5 of the existence and impact of mechanical looms, the ramifications of which in the midnineteenth century are comparable with those of the computer in our own age. Unconventionally, a similar approach is taken with characters, so that new figures are brought in constantly, even as late as the final act with Old Hilse.

There are motifs which point both forwards and backwards. An example of this is the inoculation of the men by the barber in the third act, the very centre of the play, which is endowed with a meaning beyond its literal one. ${ }^{12}$ The pride that Jaeger, Baecker and their followers take in showing off their bloody inoculation marks demonstrates that this event is to be understood as a metaphor for a rite of passage and indicates the emergence of a group consciousness within the growing band of revolutionaries. This infection with the spirit of revolution reaches its climax in act 5 where 1500 weavers are said to be on the march, but in hindsight we realise that this process acquires relevance much earlier in the drama. It has already begun in acts 1 and 2 where first Baecker, then Jaeger, inspire old Baumert with their ideas and so set the chain of events in motion.

Motifs that are similar or even almost identical to each other are introduced time and time again to give a cumulative, layered effect and add depth to an already known piece of information in much the same way that a painter goes on adding dabs of paint to a canvas until a complete picture emerges. Striking examples of this are references to the wretched lives of the weavers which inform the work from start to finish: repeated allusions to debilitating illness, exploitation, miscarriages, madness, suicide, crop failure, and starvation. This gives us not just a comprehensive portrayal of a community in strife, but of one nudging towards an even greater catastrophe. The drama is also infused with many contrasting elements and ironies which cut across boundaries and switch back and forth. They may be seen in stylistic elements, character portrayal and in aspects of detail. Their extensive use introduces a certain dynamic and tension which help to move the action

\footnotetext{
12 The two English versions referred to here in notes 2 and 11 both mistranslate the German word impfen as to tattoo.
} 
forwards, or rather in a circle, to its open-ended tragic outcome. However, as will become evident from a glance at Auguste Rodin's The Burghers of Calais, the drama's innovative features are in fact closer to those of sculpture than of painting.

The Burghers of Calais, one of the most famous of Rodin's sculptures, with a revolutionary new concept of what a monument should look like, was probably not known to Hauptmann when he wrote The Weavers. ${ }^{13}$ Rodin was commissioned to create this work in 1885, one year after Hauptmann had left Rome, to honour the memory of six legendary burghers of Calais in fourteenth-century France: when that city was besieged by Edward III of England, they made the heroic decision to sacrifice their own lives to save the city from being stormed and ransacked. On 4 August 1347 they delivered themselves to the enemy, fulfilling Edward's demand that the city should produce any six voluntary hostages wearing nooses around their necks and carrying the keys to the city and castle. While the final maquette was completed in 1889 (the year in which Hauptmann published his first drama, Before Sunrise), it took another six years for the work to be cast in bronze in 1895 , three years after the first production of The Weavers in $1893 .^{14}$

Heroic figures in monuments had traditionally been single figures, presented on a pedestal so that the viewer would behold the heroes from the front and from below with a sense of awe. Rodin, however, chose to produce one single group of six men, the aspect of all of them being equally important from whatever angle the viewer looks at them. He also placed the group on a plinth rather than a pedestal, to ensure that all six figures were viewed at

\footnotetext{
${ }^{13}$ Leppmann (n. 9 above), 198, claims that Hauptmann's partiality to artists such as Adolf von Hildebrand and Ludwig von Hofmann, along with Böcklin and Stuck, made it impossible for him to appreciate Rodin, Cézanne, Matisse and Picasso. However, Eberhard Hilscher, Gerhart Hauptmann: Leben und Werk (Frankfurt am Main: Athenäum Verlag, 1988), 46, quotes Hauptmann's delighted response, in 1906, to a written communication from Rodin's private secretary, Rainer Maria Rilke, which informed him that Rodin was willing to make a portrait sculpture of him. (The project did not eventuate.)

${ }^{14}$ However, the unveiling of the final maquette, in the 1889 installation, already established Rodin's genius internationally. See Catherine Lampert, Rodin: Sculptures \& Drawings (London: Art Council of Great Britain, 1986), 110.
} 
eye level. ${ }^{15}$ As the viewer has to walk around the group to appreciate the work as a whole, its impact is created by all of its parts rather than by certain parts being given greater importance than others. This principle of equal value of all parts applies not only to the six men in the group, who represent different ages and positions in society, but also to all parts of their bodies; their hands, gestures and postures are as important as the expressions on their faces, and even their clothes are as significant as the muscles in their bodies. Each and every one of them becomes an evocative manifestation of highly individual feelings. These contribute to the overall effect of the desperately tragic situation which unites the group $^{16}$ of disparate men who are willing to surrender to the enemy of their own free will while also being forced by the fact that they see no other option than to die for their city. ${ }^{17}$

In The Weavers, Hauptmann's eponymic heroes are just as much at eye level with the audience as Rodin's six burghers of Calais; no one figure is shown as more heroic than the rest. Although they include individuals just as different from each other as those in Rodin's sculpture, critics have identified the weavers as

15 In a magazine article of 1914, Rodin is quoted as follows: "I did not want a pedestal for these figures. I wanted these to be placed on, even affixed to, the paving stones of the square in front of the Hôtel de Ville in Calais so that it looked as if they were leaving in order to go to the enemy camp. [...] [P] assersby would have elbowed them, and they would have felt through this contact the emotion of the living past in their midst." (Quoted from Albert E. Elsen with Rosalyn Frankel Jamison, Rodin's Art: The Rodin Collection of the Iris \& Gerald Cantor Center for Visual Arts at Stanford University [New York: Oxford University Press, 2003], 86.) However, he agreed to a cast of this monument being mounted on a very tall stone pedestal in the park, next to the House of Parliament, in London, in 1915 (86-88).

${ }^{16}$ According to Harry Graf Kessler, "Griechischer Frühling," Neue Rundschau 20 (1909): 719-43, the concept of the group in Hauptmann's drama Florian Geyer (published 1905) constitutes a parallel between that drama and Rodin's sculpture, The Burghers of Calais. See Sprengel (n. 1 above), 105.

${ }^{17}$ For further discussion of Rodin's The Burghers of Calais see Josef A. SchmollEisenwerth, Auguste Rodin [Katalog zur Ausstellung; Skulpturenmuseum Glaskasten Marl, 23. November 1997 bis 1. März 1998; Musée Royal de Mariemont, 27. März bis 21. Juni 1998], Ostfildern-Ruit, 1997, and Josef A. Schmoll-Eisenwerth, Rodin-Studien: Persönlichkeit, Werke, Wirkung, Bibliographie (München: Prestel, 1983). 
a whole as the play's collective hero. ${ }^{18}$ In no way is their moral stature shown as being above or below that of the propertied and educated classes. A glance at the overall structure of the play gives an indication of some of the antitheses functioning as equal parts of the play as a whole. The five acts are so arranged that there is a juxtaposition of public, private, public, and private settings, culminating in the semi-public location of the act 5. ${ }^{19}$ Each act seems to portray the situation of the weavers from a new angle while, at the same time, pushing events forward in what initially seems a rather static drama. Act 1 is set in the spacious and airy inspection room of the cotton magnate Dreissiger in Peterswaldau where weavers come to deliver their completed fabric, act 2 in the tiny, run-down hovel of the cotton and basket weaver Ansorge in Kaschbach, who shares his abode with the six-member Baumert family. Its minuscule dimensions and poor trappings define the restricted horizons of their existence. The third act takes place in the tap room of the main tavern in Peterswaldau, where all classes of society can mingle, locals and outsiders alike. The fourth, a counterpart to the second, again introduces a private home, the sumptuously opulent, tackily-appointed Peterswaldau mansion of the wealthy Dreissiger family. In the fifth act, while focus is on the cluttered, one-roomed accommodation of the Hilse family in Langenbielau, the building clearly houses many other weaving families in equally cramped quarters. The public domain continually merges with the private sphere, as people from different classes come and go continually with descriptions about the progress of the weavers' revolution in the form of reports and

\footnotetext{
${ }^{18}$ Some examples of critics who refer to the weavers as a collective hero are: J. L. Styan, Modern Drama in Theory and Practice 1. Realism and Naturalism (Cambridge: Cambridge University Press, 1981), 51; Maurer, Understanding (n. 3 above), 41; The Houghton Mifflin Dictionary of Biography (Boston: Houghton Mifflin Company, 2003), 696. Thomas Borgstedt, "Naturalismus und religiöse Ethik: Gerhart Hauptmanns Die Weber und Émile Zolas Roman Germinal," Germanisch-Romanische Monatsschrift, vol. 54, 2 (2004), 187 and 193, points out that, while Zola's Germinal as well as Hauptmann's The Weavers aim at the audience's pity rather than at revolution, Hauptmann's play stands out by not featuring a "main figure" (Hauptfigur) or "individual hero" (individueller Held) such as Etienne in Zola's novel.

${ }^{19}$ Maurer, Understanding (n. 3 above), 47, describes the acts as loosely connected tableaux.
} 
teichoskopiai. This act has been described as a recapitulation of the whole drama. ${ }^{20}$

Perhaps not surprisingly, contrasting and conflicting elements are most vividly brought out in the publicly located acts, especially the first one, although there are important ones in the private acts as well which will also be examined.

Act 1

Hauptmann's generous and very graphic opening stage directions, a feature common to all five acts, not only place the impending action in a specific milieu but indicate the procedure imposed on the weavers as they submit their work for inspection. The class hierarchy is immediately evident, because a large table onto which they must put their webs separates them from Dreissiger's second-in-command, Pfeifer, and a smaller one from the cashier. These barriers remain in place for the duration of the act and are reinforced by less concrete obstacles:

MANAGER PFEIFER stands behind the big table on which the wares to be inspected are laid down. He uses a pair of dividers and a magnifying glass to help with the scrutiny. When he has finished the examination, the weaver puts his products on the scale, where the OFFICE BOY checks their weight.[...] The price to be paid is called out by MANAGER PFEIFER to CASHIER NEUMANN who sits behind a small table. $(5)^{21}$

The description of the weavers' demeanour and dress underlines their second-class status:

There is something of the oppressed about them, something of the receiver of charity who, going from humiliation to humiliation, is merely tolerated and expected to make himself as inconspicuous as possible. In addition, there is an inflexible feature of harassed irresolute brooding in their expressions. The men, who have much in

${ }^{20}$ Maurer, Understanding (n. 3 above), 48.

${ }^{21}$ The page numbers in brackets immediately after the quotations refer to Frank Marcus' translation of The Weavers. (See $\mathrm{n} .11$ above) 
common with each other, half dwarfish, half schoolmasterly, are predominantly sunken-chested, coughing, poverty-stricken people with dirty, pale complexions: creatures of the loom, whose knees have become bent as a result of excessive sitting. Their women look less typical at first glance; they're broken, harassed, exhaustedwhereas the men still show a certain pitiful gravity - and ragged, whereas the men's clothes are patched. (5-6)

Their ill and down-trodden appearance contrasts crassly with Pfeifer's ("well-nourished, decently dressed, clean-shaven and a vigorous taker of snuff" [6]) and Dreissiger's, a fat, asthmatic man with a stern look.

These stage directions also hint at inequalities between the duties and expectations of the sexes in the weaving community. The female figures at least attempt to make their men look more presentable by mending their clothes, but attention to their own clothing is out of the question. Their double burden of being wives and mothers ${ }^{22}$ as well as weavers is reinforced in act 2 with the tribulations of the two Baumert girls and Frau Heinrich who have to feed their families on the smell of an oily rag and in act 5 with the figure of Luise Hilse, whose rabid embrace of the revolution is entirely motivated by her on-going frustration at being unable to provide even enough nourishment to keep her children alive. Their circumstances are totally at odds with those of the ditzy, vacuous Frau Dreissiger in act 4 who can call on the assistance of servants to relieve her of household and child-rearing duties.

Class differences are stressed further by Hauptmann's pointed allusions in stage directions to body language and tone. In this respect the First Weaver Woman, Heiber and Reimann may be taken as symbolic examples from among the weavers in act 1 . Their repeated approaches to Pfeifer and Neumann in an effort to obtain small increases in their meagre wages are accompanied by highly significant gestures and inflections, theatrical equivalents of

${ }^{22}$ By virtue of their selfless and, by necessity, self-destructive work for their husbands and children, the weaver women come the closest of all the figures of the play to the six self-sacrificing burghers of Rodin's sculpture. In his essay "Versuch über das Scheitern: Zu Gerhart Hauptmanns Geburt der Tragödie aus dem Geist des (Selbst-)Opfers" (in Deutsche Vierteljahrsschrift für Literatur und Geistesgeschichte, Nr. 76 [2002]), Peter Hofmann mentions neither The Weavers nor The Burghers of Calais. 
the exaggerated gestures, postures and "speaking" hands in Rodin's sculpture:

1st WEAVER WOMAN (imploring excitedly). (6)

WEAVER HEIBER suppresses tears, stands humiliated and helpless. (8)

WEAVER REIMANN [...] in an injured and accusing tone. (17)

Their requests are met by the confident and often derisory behaviour of the authority figures like Pfeifer who distinguishes himself with his use of sarcasm, shouting and anger.

Underlining gesture and tone are the events themselves which point to the fact that there is virtually no real dialogue or effective inter-communication between the weavers and their employers, making the solution of problems an impossibility. Throughout act 1, Pfeifer gives orders, speaks derogatorily to his off-sider about the weavers as though they were absent, ignores their requests, treats them like children by telling them to be quiet, or attends to the next weaver in the queue while the previous one is still waiting for information. The content of the employers' words often highlights the extent of their prejudiced misunderstanding of the realities of the weavers' lives. They see them as lazy good-fornothings who squander their money and frequent the tavern, a notion heard sometimes today with regard to the unemployed. ${ }^{23}$ While insisting that his own time is precious ("I haven't got the time. That's done with" [7]), Pfeifer, as the man with jurisdiction over them, has no compunction about holding up these people, whose lives are entirely dictated by the need to keep working:

OLD WEAVER. [...] A weaver can wait an hour or a day. A weaver doesn't count. (7)

Nowhere is the middle-class lack of understanding of the workers more vividly displayed than in the fainting episode involving the Heinrich child. Forced already at his tender age to

23 The weavers in their conversations with each other show a similar misunderstanding about the situation of their employers. The tariffs and pressures of the economy which Dreissiger describes to them at the end of act 1 have no relevance to their world and they simply attribute his behaviour towards them as being motivated by meanness (act 2,30 ). 
forego education in order to contribute to the family living by weaving and playing music, the young boy contrasts sharply with Anna in act 3 who can spend her time embroidering and Dreissiger's two boys in act 4 who enjoy all the advantages of a home tutor and, like their parents, have ample leisure time at their disposal. From his cushioned perspective, Dreissiger fails to comprehend the child's hunger; in fact his dismissal of the weaver woman's advice to feed the child shows that it is inconvenient and not in his own interests to do so; instead, he inappropriately calls for the administration of brandy, berating the parents for their abuse of their boy and declaring a veto on the further acceptance of weaving from a child of this age. (Ironically little Mielchen in the fifth act, who returns home with the silver spoon found outside Dreissiger's house, is the only figure from amongst the weavers ever to receive appropriate payment by the factory owner, and this only by default.) His belief that what he doesn't see, or in this case, know, will not hurt him, is reintroduced in act 4 where he suggests that he and his guests retreat to a back room for a game of whist rather than having his peace disturbed by what is becoming a grave industrial situation on the street in front of his house.

The employers treat the weavers like objects on a conveyorbelt, like easily replaced commodities. Hence Dreissiger's readiness to employ 200 more weavers, even though it will mean considerably reduced wages for the existing ones. Far from being a magnanimous gesture, he takes on more in order to present himself in a philanthropic light, without his having to dig deeper into his pocket. Paradoxically, instead of protecting the commodity which has helped to make him wealthy, he and his assistants continually admonish the weavers for sloppy work, expecting them to produce perfect cloth from the substandard yarn they themselves have presented them with in the first place.

Ignoring the genuine tales of the weavers' hardship, they strive to shield themselves from too close a contact with their employees. To the physical barriers of the tables the employers add invisible but equally powerful ones like obstructive behaviour and a constant passing of the buck. The cashier, Neumann, refuses to give the First Weaver Woman an advance, claiming it is Dreissiger's domain. Her access to Dreissiger, however, is blocked by Pfeifer. Only at a moment of crisis, when the renegade weaver Baecker makes a scene, is Dreissiger lured out of his back room, and once this and the fainting crisis are dealt with, he beats a hasty 
retreat again, referring the First Weaver Woman, Reimann and Heiber back to Pfeifer. Dreissiger himself succinctly sums up his communication difficulties with the weavers at the end of act 1:

DREISSIGER. I don't know what you are talking about. (18)

Communication is therefore a one-way street. Dreissiger's refusal to make any effort to comprehend his workers and the resulting deadlock help to trigger the train of events with their tragic consequences for the weavers. Their own inarticulateness and the ignorance of the middle classes about their plight are reminiscent of Büchner's Woyzeck. The protagonist in that play, a simple soldier from the same class as the weavers, is, like them, forced to serve many ignorant but middle-class masters, in order to make enough to feed his family. Although the fragmentary nature of the play makes it impossible to say with complete certainty how Büchner visualised the final shape of his work, it would not be farfetched to maintain that the unsustainable pressures on Woyzeck and his inability to make himself understood eventually lead him to murder his mistress. A comparable situation with the weavers ultimately leads these quiet, harmless people to commit violence and criminal actions and brings about an outcome totally different from the one they intend.

Into act I comes the first of a small number of characters who stand out from their peers as being unusual in a significant manner. If a breakdown in dialogue forms one of the triggers for the action, it would undoubtedly not move forward without the presence of this second component. This comes initially in the form of Baecker, "a young, exceptionally strong weaver [whose] demeanour is unconstrained, almost impudent" (6). His reputation as a troublemaker is evident from Pfeifer's wary attitude towards him, and the allusion to the fact that he has been heard singing the Song of Blood and Justice. ${ }^{24} \mathrm{He}$ is apparently unencumbered by the large numbers of dependants of his peers, and there is nothing of their fawning, cowed behaviour in his reaction to his employers. His stroppy attitude and fearlessness may account for the fact that he is offered significantly higher wages for his web than others, 13 $1 / 2$ Groschen (as opposed to pay as low as 10 Groschen), an

\footnotetext{
24 This revolutionary song becomes the theme song of the weavers' revolt and a unifying element, because it is either alluded to or heard in each act.
} 
amount which he proceeds to query in a loud and argumentative manner:

BAECKER. [...] It's a shabby tip, nothing more. And for this we're supposed to work our treadle from early morning to late at night. And when you've worked the loom for eighteen days, night after night, drained, and half dead with the dust and the burning heat, then you're lucky if you've made thirteen and a half silver groschen. (11)

His behaviour suggests, nevertheless, that a confrontational attitude might well pay off. He is the only person Dreissiger is prepared to leave his office for, and paradoxically, Baecker unnerves him to such an extent that Dreissiger's speech breaks down and becomes disjointed, a trait until now seen only with the weavers when they have to face their employers:

DREISSIGER. There's your pay; and if you don't get out at once ... It's twelve o'clock, ... my dyers are going off to lunch ...! (13)

His altercation with Dreissiger might be described as a miniature version of the confrontation in act 5 between weavers and authorities in the form of the army which takes place off-stage. Baecker functions as a type of inspirational role model for his docile friends who until now have felt powerless to alter their lot but who begin to comprehend the sense of his actions. With his spunky behaviour, he shows them another option, and this, combined with their untenable situation, allows the action to proceed to the next stage.

Act 2

In the rotting, soot-blackened home of Ansorge and the Baumert family with its noise, polluted atmosphere and challenging domestic situation, the focus in act 2 is entirely on the lower class; whilst showing, on the one hand, the common difficulties faced by the weavers, this act also reveals diversities in terms of fortunes and Weltanschaunng which make the weavers a textured and disparate group. 
From Dreissiger's harangue at the end of act 1, we know that the linen weavers in the district are considerably worse off than his cotton weavers, but act 2 makes it quite clear that there are degrees of poverty even amongst this latter group. Poverty is a relative term. The destitute and pregnant Frau Heinrich, mother of the child who has fainted in the previous act, her face expressing "tortured anxiety and fearful tension" (22), arrives on the pretext of requiring help with a splinter, but really hopes for some modest food for her nine children. To her the starving Baumerts are well off. Unlike her husband who has had a fit and can't work at all, Old Baumert can still pull his weight, and his 15 and 22 year old daughters can make a greater contribution to the housekeeping than her own much younger children. Her real misfortune, in contrast to Luise's in act 5 who has lost several children to poverty, is that her children are all alive and a drain on the household. This poor community can not afford to carry drones.

A grotesque, antithetical element and one quintessential to the development of the action is the figure of Moritz Jaeger, just such a one-time drone. Unlike Pfeifer, who was once a weaver and whose upwardly mobile ambitions exclude any fraternisation with his former peers, Jaeger returns to the family fold like a type of prodigal son, after a stint in the army. He represents an intensification of Baecker; by leaving the community, he has gone much further than him, sloughing off his old skin and his old way of speaking ${ }^{25}$ and broadening his horizons by acquainting himself with conditions and views held in the outside world. Sharing with Baecker a boastful and aggressive manner, he is, however, a much wealthier man than him, as his sartorial elegance demonstrates:

[He is] a sturdy, red-cheeked Reservist of medium height. His Hussar's cap is set at a jaunty angle and he wears a smart uniform, polished boots, and a clean, collarless shirt. Having entered, he stands to attention and gives a military salute. (24)

Far from being the object of his relatives' envy, he is greatly admired for the remarkable extent of his transformation. Unable to

\footnotetext{
25 Much attention has been paid to the language of the drama and the role dialect plays in it. Hauptmann uses it, amongst other things, as a definer of class and character. The extensive and subtle use of dialect makes this drama extremely difficult to translate effectively into English.
} 
master even the most rudimentary techniques of weaving, he was the ultimate burden on his family, preferring to occupy his time with worthless pursuits like bird snaring. His unusual childhood activities, though, would seem to indicate a certain independence of spirit, a trait common to all those who aspire to, or manage to break out of, the weaving rut. Once in the army, he has soon had the system worked out and has exploited it to his own advantage:

I got my stripe after six months. You've got to show willing, that's the main thing. I polished the sergeant's boots, I groomed his horse, I fetched his beer, I was as sharp as a weasel, always there: cleaned the canons till they shone. [...] I thought to myself, you'll get no help from anyone, you're on your own. (27)

Ironically, in his new world, hard work has paid off handsomely, whereas the opposite is the case with his relatives in Silesia, despite Pfeifer's assertion that "if you work hard and know what you're doing [...] then you'll never need an advance" (8).

Whereas act 1 demonstrates how their problems are ignored on a local level, Jaeger's experience in the outside world has shown him that their problems are also ignored by the highest authorities, especially by those who have the most. As an 'insider-outsider' with a foot in two camps, he can comment knowledgeably on the situation:

JAEGER. [...] the rich, they twist and turn ... they can outwit the best Christians. (29)

His call to arms falls on fallow ground and, in this small audience, has the galvanising effect of the words of a motivational speaker:

JAEGER. [...] we don't need the King or the Government for that. We could just say we want this and that or this and not that and they'd soon whistle another tune. If they saw us sticking together they'd soon show us the white flag. I know those pious brothersthey're a lot of cowardly bastards. (31)

His suggestion is an intensification of the demands in act 1 successfully made by Baecker, with whom we hear Jaeger has in 
the meantime formed an alliance. In Jaeger's intonation, though, there is already a hint of the failure to come, because his adolescent naivete and passion unleash emotions which are intense and ultimately uncontrollable:

He reads, haltingly, like a schoolboy, with wrong emphasis, but with unmistakable passion. Everything is in his voice: pain, anger, hate and thirst for vengeance. (32)

Act 3

Set in the tavern at Peterswaldau, act 3, with its rather chaotic discussions, disagreements, bantering and constant comings and goings, initially seems to present a totally new situation with little connection to previous events. Round the figures of the publican and his wife rotate a host of characters who each add their own hue to the picture of this community, making this scene pivotal to our understanding of the forces at work there. Evident, though, are previously encountered motifs and conflicts in a different guise.

The lowliest members of society are always present, firstly through the funeral hymns which penetrate into the tavern like a type of musical score and provide the topic of conversation, and then in person as they use the inn as their rallying point for their revolutionary activities. Present, too, either physically or in conversation, are some of their middle-class oppressors about whom we have already heard, entrepreneurs of Dreissiger's ilk, whose work the weavers must do in addition to their primary occupation to help make ends meet. Illustrating graphically weaver Baumert's statement that "a weaver is like an apple-everyone takes their bite" (43), many of these figures, in what amounts to cameo appearances, condemn themselves by their own statements. Wiegand, the carpenter with seven apprentices, exploits the dying "with cunning, quick-wittedness and ruthless ambition" (36), characteristics not so different from Dreissiger's, whose part he takes over the latter's employment of 200 new weavers. The forester arrives in search of wood thieves amongst the weavers, and the peasant condemns them for drinking, gambling and an inability to plough a straight furrow. The policeman, Kutsche, who delivers an ultimatum from his superior, vetoing the singing of the 
Song of Blood and Justice, reveals his prejudices when he states that the weavers would never be satisfied regardless of how much food they received.

Embroidered into the text are also references to others who have profited. Anna Welzel's ambition to marry up, out of her class, is applauded as being like Dreissiger's grandfather and Tomtra with his 12 estates. The very unchristian greed of the ministers who encourage the weavers to put on lavish and cripplingly expensive funerals is also alluded to.

The picture is balanced out in act 3 by the presence of figures, not just from opposing ends of the social spectrum but from along this spectrum as well. Hornig, a rag and bone man of some substance, is a neutral character, able to associate easily with the middle and lower classes, as we see both here and in the final act where he reports to the weavers that he has shown the councillor through the ruins of the Dreissiger residence. By no means uncritical, he has no compunction about accusing people from his own class of gross exploitation and is also able to give the travelling salesman an unbiased account of the false picture of the weavers' plight in the press and the reasons for this. Wittig, the smith, fulfils a similar role.

The travelling salesman as the only total outsider in the drama is a foil to the local people. He functions as a dramatic device through which Hauptmann can illustrate the prejudices of the outside world about the weavers, touched on by Jaeger in act 2 . A showily dressed name-dropper, able to dine on steak, he represents those in nineteenth-century German society who endowed the weaving trade with mythological and mystical elements because of its long and venerable history. This is illustrated by his erroneous assessment of the enervated Ansorge, whom he views as a type of zoo animal:

SALESMAN. Such figures of strength are very rarely seen these days. We've been weakened by civilisation, I'm always pleased to see an example of natural man. Look at his bushy eyebrows and his wild beard. (39) 
Act 4

While taking us into a private domain, the cold but opulent home of Dreissiger, act 4 differs from its counterpart, act 2, in that all dialogue and action are coloured by the unrest outside and the eventual infiltration of the rebellion into the heart of Dreissiger's private world. The scene portrayed here is therefore not as exclusively private as in the second act.

Act 4 introduces us to Pastor Kittelhaus, the representative incarnate of the local Lutheran church whose encouragement of opulent funerals has been vividly described in the previous act. In his encounter with three different individuals or groups, his unsuitability for the profession he has taken up becomes clear. His exchange of views with Dreissiger's nineteen year old tutor, Weinhold, represents his first highly significant clash with ideals contrary to his own. Kittelhaus, a friendly, well-meaning but misguided man, dismisses Weinhold's views as an aberration of youth. Like Dreissiger with regard to the weavers in act 1, he does not care to hear Weinhold out, but instead pontificates and addresses him in a "reproving" tone. Like his rich friend, too, he wriggles out of his responsibilities towards his flock:

KITTELHAUS. [...] Guardians of the soul should not become guardians of the flesh. Preach the Word of God purely and simply and leave it to Him to provide shelter and food for the birds. He will not suffer the lily of the field to perish. (54)

Weinhold, on the other hand, said to hold views similar to Hauptmann's at the time of the drama's inception, has an excellent understanding of the weavers' problems and sympathy with them, describing them as "hungry, ignorant people, [who] show their discontent in the only way they know" (56). From a good family, he is the only middle-class character in the drama who is able mentally to cross the divide downwards or who makes any attempt to do so. His humanitarian principles, however, are met with ridicule by others of his class, and he is pilloried and dismissed for them. It is probably not by chance that he is described as being "pale, thin and gangling, with long, blond hair [...] very nervous and restless in his movements" (54). His appearance is reminiscent 
of the Baumert girls, for example, who have light blond hair and thin shoulders.

Kittelhaus' second encounter is with Jaeger after the latter's brief arrest. His efforts to appeal to Jaeger's conscience as a former member of his congregation are fruitless, and his answer to Jaeger's remark that he has put money in the plate and has therefore paid his dues, is highly ironic when viewed against the unflattering descriptions of the money-grabbing church in act 3:

KITTELHAUS. Money, money! Do you really think that a miserable coin ... keep your money ... I'd rather you did. What nonsense that is! Be good, be a Christian, remember your faith. Keep God's commandments, be virtuous and be pious. Money, money... (60)

His third encounter is off-stage with the weavers themselves, with whom he attempts to negotiate. Motivated not by altruism but purely by a curiosity to see whether he still commands respect, his actions result in his death at the hands of the very people he has betrayed and indicate that a "lily of the field" does in some cases perish.

His host, Dreissiger, while somewhat distracted and excitable, obdurately adheres to his behavioural patterns of act 1 , protesting his own innocence and favouring flight into the back room for coffee and a game of whist over dialogue with the emboldened weavers rattling at his doors. Had he heeded and acted upon his coachman Johann's remark that the weavers were calling for more money, the crisis might yet have been averted. His confrontation with the captured Jaeger, which is forced on him by circumstances, has something in common with his clash with Baecker in the first act, but its impact on him is cushioned by the presence of the superintendent of police, who takes over proceedings. In typical fashion he has again passed difficult decisions over to someone else. Pfeifer, too, on hearing the crowd baying for his blood after the release of Jaeger, attempts a similar maneouvre. He hysterically grasps at Dreissiger and throws himself on his mercy, his words proclaiming that his treatment of the weavers was governed by orders from above bearing an uncanny similarity to the defence sometimes put forward by perpetrators of crimes against humanity after the fall of the Third Reich and the East German state: 
PFEIFER. [...] I've always served you faithfully; and I've always been good to the weavers. I couldn't give them more pay because it wasn't up to me-don't leave me, they'll kill me. (66; emphasis mine)

Paradoxically, Dreissiger's initially fallacious perception of the weavers as lazy louts given to alcoholic bingeing begins to attain a grain of truth as a result of their visit to the inn for Dutch courage. This is confirmed by the conduct of Jaeger, whose innate defiance is intensified by his consumption of alcohol, causing him to taunt the maid and Frau Dreissiger, spit on the floor and reveal his halfbaked ideas by declaring himself a Quaker, people he mistakenly equates with atheists. The tragedy that the weavers have had to rely on such an incompetent hot-head to ameliorate their situation is becoming evident.

The final part of the act, which witnesses the entry of the weavers into the house after the flight of the Dreissigers and their guests, at first shows timidity and restraint. Just as the weavers have been totally overawed in the presence of Dreissiger in act 1, they are overawed in the presence of his trappings. But just as their confidence has increased as the drama progresses, they quickly gain confidence here, too, at first merely testing out sofas and mirrors, then resorting to vandalism. With the entry of the ringleaders, they complete their transformation from docile and cowed people to violent and vengeful ones, whose plans include the destruction of Dreissiger's establishment, followed by a move to Bielau "to Dietrich who uses mechanical looms. It's the factories that cause all the misery" (68). This almost incidental remark, reiterated in act 5 by Hornig, conceals within it the true tragedy of the play: the weavers' inability to comprehend the significance of the new technology for their lives and to master it for themselves. It becomes apparent that an open-minded reaction to this, rather than a negative and destructive one, is where their true salvation lies. Words of anthropologist Michael Asher sum up their situation well: "The true threat to existence lies not in change, but in becoming entrenched in a rigid response to a universe which is itself always changing." 26

${ }^{26}$ Michael Asher, The Last of the Bedu: In Search of the Myth (Harmondsworth: Penguin, 1996), 283. 
Ansorge stands for all his fellow weavers when at the end of act 4 he demonstrates both his own disbelief in his actions and the fact that he too has been infected with the fury of the ring leaders:

I've gone crazy! I don't know what's going on, I'm not right in the head. Go away, go away!

Get out, you rebels! Heads out, legs out, hands out! You take my little house, I'll take your little house. Come on, let's go! (68)

Act 5

The enigmatic fascination of the fifth act of The Weavers stems largely from how one is to understand the character of Old Hilse who appears here for the first time and whose presence dominates the action from now on. Although Hauptmann has a propensity to introduce new characters throughout this drama, they are, generally speaking, subtly prepared for by means of comments in a previous act. This is true of the oppressors in act 3, for instance, whose existence is alluded to by the weavers earlier on. Old Hilse is in a category of his own in this respect, his sudden, unheralded appearance seeming to come like a bolt from the blue. ${ }^{27}$

Act 5 has been described as a small drama in its own right, having only loose connections with the preceding events. ${ }^{28}$ However, it is true to say that Hilse can only credibly exist against the background of the revolution he so vehemently disapproves of and which has been so carefully prepared in the first four acts. He

\footnotetext{
27 Some commentators claim that Hilse was an attempt by Hauptmann to water down his portrayal of the revolution and better his chances with the censors. It is certainly true that Hilse's deep religious convictions run counter to those of the dramatist. See Warren R. Maurer, Gerhart Hauptmann (Boston: Twayne, 1982), 53-56.

${ }^{28}$ Hans Wolff, Gerhart Hauptmann (Darmstadt: Wissenschaftliche Buchgesellschaft, 1976), 253. This opinion seems inaccurate when one considers the references in act 5 to events that have begun in act 4 and which need to be understood by characters in the fifth act if the action is to be plausible. Hornig gives an eye-witness account of the ransacking of Dreissiger's mansion and later Surgeon Schmidt links the two acts firmly together with his description of the weavers' march from Peterswaldau to Langenbielau.
} 
shares with his fellow weavers their abject poverty. His miserable little room in Langenbielau, which is also home to his wife, son Gottlieb, daughter-in-law Luise and granddaughter Mielchen, has much in common physically with the Baumert abode, as does his bearded, pale figure with Ansorge. It is his Weltanschauung which sets him apart from them so dramatically at this point in the play, creates tensions and conflict within his own family and infuses the final act with an unexpected energy. His outlook is a very extreme version of what the weavers used to be like when the action began.

His unquestioning, deep religious faith and his upright principles cause him to clash headlong with Luise whose insolence and assertiveness make her immediately identifiable with Jaeger and Baecker. She trembles with excitement at the news of the approaching rebellion which she views, like the other weavers, as her possible salvation; the experience of losing her children to poverty leaves no room for idealism and the abstractions of religion in her life. Hers is a search for practical remedies in the here and now.

Even her attitude to death is at odds with her father-in-law's. In general death is seen in The Weavers as more of a merciful release than a devastating event; while it has brought Luise personal sadness, she also acknowledges it as a friend who takes pity on an innocent soul. She doesn't want her children to have to suffer but has no specific vision of an afterlife. Hilse, on the other hand, has been sustained for years by an unshakeable conviction that death will provide him with a life he has been unable to enjoy on earth and which will ultimately make his present discomfort worthwhile.

Their irreconcilable views are especially evident in their attitudes to moral issues. The silver spoon found by Mielchen outside Dreissiger's house is seen by Luise as literally a life saver, while to Hilse it is "the devil's spoon" which must be returned forthwith. Her attitude, like that of many of the weavers forced into petty crime by poverty, can be appropriately summed up with the Brechtian maxim: "First comes food, then comes morality." 29 To Hilse, though, morality and good impressions must be upheld even in the direst of situations, as is clear when he admonishes Luise for

${ }^{29}$ Bertolt Brecht, Die Dreigroschenoper (Stuttgart: Suhrkamp Verlag, 1968), 69. My translation. 
calling her husband, who is wedged uncomfortably between the opinions of his wife and his father, a milksop:

OLD HILSE (shaking with fury). And you call yourself a woman? I'll tell you something - you may be a mother but you've got a wicked tongue. You set yourself up as an example to your child and then you push your husband into crime and lawlessness. (77)

The extremes of the family quarrel are mirrored in Hilse's dialogue with his old weaver friends at the end of the drama. His dogged individual stand against persuasive arguments of the weaver collective to join the fray demonstrates the strength of his moral fibre.

For all his entrenched attitudes, it is Hilse who sees the futility of this haphasard revolution conducted by people armed only with beanpoles, hooks and axes, "trotting along, one behind the other, looking like death warmed up and singing and making a terrible din" (76). Echoing the words of Wittig in act 3 who predicts bloodshed and defeat even before the uprising gets underway, Hilse correctly assesses their meagre chances against the superior might of the army, and in the end he and his old friend Baumert have to agree to differ:

OLD BAUMERT. [...] You were right, Gustav, I am a little drunk, but I'm still clear in my head. You've got your view of things and I've got mine. I say Baecker is right - if it ends in ropes and chains, it'll still be better in prison than home. You're looked after there, you don't have to go hungry. I'd have preferred not to join them but you see, Gustav, a man must breathe fresh air just once in his life. (85)

The ultimate irony of the drama lies in the fact that innocent Hilse, who has served loyally in the army in his younger days and has opted for non-involvement in the revolt, becomes a victim of a stray bullet fired by the army and gets precisely what he wants, death "rather today than tomorrow" (78).

It is part of the tragedy of The Weavers that the confidence which seemed to offer the weavers such a beacon of hope in the figure of Baecker in act 1 and which has replaced their cowed attitude as the drama progresses, will not bring about a change in their fortunes. On the contrary, the wheel has turned full circle and 
their repulse of the troops at the end of the play, will, as Hilse has predicted, be only a temporary victory. They win the skirmish but will lose the struggle and will ultimately be as badly off as before.

Thus Hauptmann's play ends without an end, in a circle, so that ultimately it does not matter where the circle is begun and completed. However, the audience was far from frustrated or bored by the apparent futility of the action, and was not simply moved by the plight of the title figures on stage either. On the contrary, it was the staging debacle surrounding this drama which brought Hauptmann recognition and notoriety well beyond Germany's borders, as the content of The Weavers proved to be an explosive political issue. This was quite different from the revolutionary effect of Rodin's The Burghers of Calais on the art scene, often interpreted by critics as "democratisation" of sculptures and monuments. ${ }^{30}$ A clue to The Weavers' contentiousness is partly to be found in the social situation in Germany at that time. To many, this historical work, which Hauptmann was careful to place in its historical context by means of the subtitle, seemed a thinly veiled criticism of the weavers' situation in Wilhelminian Germany. The plight of the weavers had not changed since the $1840 \mathrm{~s}$, and was still an all too relevant issue. Debate over their welfare had been rekindled because of a potato famine in the early $1890 \mathrm{~s} .{ }^{31}$ By proxy the work also seemed to be a rather too accurate and embarrassing mirror of wider contemporary society with the exploitation of the workers especially by the newly rich.

Hauptmann's application to stage the drama led to "the most spectacular censorship trial in the history of German literature". 32 Officially censorship had been abolished in Germany by this time, but because of fear of the influence of the socialists, the police had a policy of keeping a critical eye on theatrical productions.

On 20 February 1892 an application was made to the censor's office for permission for the dialect version to be performed at the Deutsches Theater in Berlin. This was declined on the grounds that

\footnotetext{
${ }^{30}$ http://de.wikipedia.org/wiki/Auguste_Rodin, accessed on 23 January 2010.

31 Articles appeared in the popular press, like those of Pastor Ernst Klein who attempted to raise public awareness of the problem (Maurer, Understanding [n. 3 above], 42).

32 Manfred Brauneck, Literatur und Öffentlichkeit im ausgehenden 19. Jahrhundert: Studien zur Rezeption des naturalistischen Theaters in Deutschland (Stuttgart: Metzler, 1974), 51.
} 
the drama gave too graphic a rendition of the factory owner Dreissiger's exploitative behaviour and the ransacking of his house by the weavers. Hauptmann was even accused of having written the work in dialect to make it better understood by the workers.

On 22 December 1892 the mixed-language, somewhat modified second version was put forward for scrutiny. In January 1893 this, too, was banned, despite Hauptmann's lawyer arguing that its content was historical and therefore not applicable to modern life. An appeal was rejected in March 1893. It was believed that this version was potentially even more problematic than the dialect one because a wider audience could understand it. ${ }^{33}$ Hauptmann then took the case to the Royal Prussian Appeals Court. On 2 October 1893 permission was finally granted for production at the Deutsches Theater on the grounds that the seats would be out of the price range of the sorts of people who might be susceptible to its political message! This was not a blanket permission, however, and each time a producer wished to stage it in Germany, the same procedure had to be undertaken again. Even then the public premiere of The Weavers did not take place until 25 September 1894 at the Deutsches Theater in a production by Cord Hachmann under the personal guidance of the dramatist.

In the meantime, however, Hauptmann was able to get around the embargo by allowing the work to be played by private theatre companies which were not bound by the laws regarding public performances. Otto Brahm's Freie Bühne, a private theatre in Berlin along the lines of André Antoine's Théâtre Libre in Paris, performed the drama for a specially chosen audience on 26 February 1893. On 15 October of the same year, it appeared at Bruno Wille's Neue Freie Volksbühne, and from 3 December it ran for a week at Franz Mehring's Freie Volksbühne. All these occasions were outstanding successes. The first truly public performance, though, caused pandemonium among various factions of the audience to rival that witnessed at the premiere of Before Dawn in 1889. The Kaiser was so incensed by the drama that he gave up his royal box at the Deutsches Theater and refused to allow Hauptmann to receive the Schiller Prize in 1896 for The Weavers and Hannele. His action merely added to public interest in

33 M. Boulby in his introduction to Gerhart Hauptmann, Die Weber (London: Macmillan, 1962), 24. 
the play and boosted box-office takings. It was performed 93 times in its first season. ${ }^{34}$

In an interview in February 1894, Hauptmann described his own motivation for writing the drama as follows: "I have hoped that the well-to-do folk who see my Weavers may be moved by the appalling misery which is reflected in that work - a misery with which I have been brought in contact and which has moved me strangely. ${ }^{, 35}$ In this somewhat understated comment he is referring to his association with Silesian weavers in his youth. Born on 15 November 1862 in the Silesian town of Ober-Salzbrunn, he was the youngest of four children of inn-keeping parents whose busy existence allowed little time for a close family life. As a consequence, young Gerhart was often left to his own devices, and he was able to become acquainted with the circumstances of many different types of people including workers such as local weavers. His parents' inn, whose cross-section of customers formed a microcosm of the community, further enabled him to rub shoulders with many different classes and people of various nationalities. ${ }^{36}$ His recognition of the significance of the inn as a hub of the community and its value as a melting pot for ideas found its way directly or indirectly into several of his dramas such as Before Dawn, The Weavers and Drayman Henschel. But only The Weavers he dedicated to his father, Robert, who had told him stories of his grandfather, Carl Ehrenfried Hauptmann, who had been a weaver for a short period before becoming an innkeeper after the Wars of Liberation. He eventually became the proprietor of the Hotel Krone in 1839 where Hauptmann grew up.

However, Hauptmann was far from being a political activist, let alone a radical one. ${ }^{37}$ While he described his own motivation for writing the drama as wanting to help to raise awareness of the weavers' plight, he made it quite clear that he wished to arouse pity

\footnotetext{
${ }^{34}$ Peter Skrine, Hauptmann, Wedekind and Schnitzler (New York: St. Martin's Press, 1989), 42.

${ }^{35}$ Meltzer (n. 6 above), 127.

36 This was atypical of Germany at the time which was a very stratified society, allowing for little movement or interaction between classes.

${ }^{37}$ Klaus Scharfen, Gerhart Hauptmann im Spannungsfeld von Kultur und Politik 1880 bis 1919 (Bristol, Berlin: Tenea, 2007), 29, even claims that Hauptmann indirectly, through statements of his solicitor Grelling, supported the politics of the government.
} 
for their predicament but not to start a revolution. ${ }^{38}$ Proof that he did have socialist tendencies at about the time when he wrote The Weavers would seem to be provided by his foundation with his brother Carl and friends of a Pacific Society to be run along the lines of the communal settlements founded in Illinois and Texas by Etienne Cabet, and Maurer points out that this episode contributed to Hauptmann's reputation as a socialist agitator. ${ }^{39}$ But these plans came to nothing.

Thus Hauptmann's social commitment to the weavers of his own time, including in his play, is just as undeniable as the fact that he found it difficult to acknowledge that commitment after the drama had been published. While there appears to have been no such precarious relationship between Rodin as the sculptor of The Burghers of Calais and Rodin's political views and activities, ${ }^{40}$ the half-heartedness of Hauptmann's social commitment is perhaps paralleled to some extent by the politically non-committal interest in the working class displayed by Rodin's private secretary during the years 1905-1906, the German poet and prose writer Rainer Maria Rilke. But there is a much more interesting parallel between the author of The Weavers, Gerhart Hauptmann, and the German "performance artist, sculptor, installation artist, graphic artist, art theorist and pedagogue of art," "J1 Joseph Beuys, who was one of the most influential artists of the second half of the twentieth century. ${ }^{42}$

38 See Maurer, Gerhart Hauptmann (n. 27 above), 11. According to Ernst Günter Fröls, Die Weber in der Revision: Untersuchungen zu Quellen, Struktur und Intention von Hauptmanns Weberdrama (Frankfurt am Main: Peter Lang, 2005), 15259, Hauptmann aimed at arousing in the bourgeois audiences of his tragedy not only their pity for the plight of the weavers, but also fear for their own fate, to encourage them to improve the social conditions of the weavers as it would be in their own interests. Hilse's death in act 5 from a stray bullet fired by the army shows the audience that the plight of the weavers, unless mitigated by the pity of the rich, must be expected to have fatal consequences not intended for anyone, including the innocent (ibid., 146-52).

${ }^{39}$ Maurer, Gerhart Hauptmann, (n. 27 above), 11.

40 The revolutionary sculptor of The Burghers of Calais never gave cause for suspicion of harbouring revolutionary tendencies in politics.

${ }^{41}$ http://en.wikipedia.org/wiki/Joseph_Beuys, accessed on 23 January 2010.

42 For a nuanced debate of Beuys' work and life see Joseph Beuys: The Reader, ed. Claudia Mesch and Viola Michely (Cambridge, Massachusetts: The MIT Press, 2007). 
In his theoretical teachings, he expanded the traditional concept of art as artefact or artistic performance by defining "social sculpture" (soziale Plastik) as any creative activity contributing to an improvement of society and of our world as a whole. His most often quoted formula for "social sculpture", coined in 1967, states categorically: "Every human being is an artist, a freedom being, called to participate in transforming and reshaping the conditions, thinking and structures that shape and inform our lives." ${ }^{.43}$ In accordance with this concept of art, Beuys became interested in environmental politics. In 1979 he became a candidate for the Greens in the elections to the European Parliament, appearing on the campaign trail side-by-side with the spokesman of the left-wing German student movement of the 1960s, Rudi Dutschke. ${ }^{44}$ But he was not elected, and while he continued to attend party conferences and to design posters for them, ${ }^{45}$ he could never persuade the Greens to adopt his political ideas.

In a way, Beuys' proposition that any action having a positive impact on society must be seen as a work of art was the opposite of Hauptmann's trusting belief that he was better placed to improve society by improving the art of drama than by getting involved in politics. Yet there remains a clear parallel in their naïve and irrational belief in art as the only remedy for the shortcomings and injustices of society. ${ }^{46}$ The irrationality of Beuys' aesthetics, perfectly evident in his statement of 1979 that "[o]nly art is capable of dismantling the repressive effects of a senile social system that continues to totter along the deathline: to dismantle in order to build A SOCIAL ORGANISM AS A WORK OF ART ${ }^{p, 47}$ has been duly attacked by critics such as Hans Platschek. Noting that Beuys' art works are only part of an elaborate performance art through which mundane objects take on a mystical, symbolic aura,

43 The Social Sculpture Research Unit, Oxford Brookes University, uses this sentence as a motto on its homepage: http://www.social-sculpture.org, accessed on 23 January 2010.

${ }^{44} \mathrm{http} / / /$ en.wikipedia.org/wiki/Joseph_Beuys, accessed on 23 January 2010.

${ }^{45}$ In 1982 he tried in vain to be elected as a candidate of the Greens for the elections to the German Federal Parliament.

${ }^{46}$ As far as could be ascertained, there is no record of Beuys ever having read, seen or mentioned any of Hauptmann's plays.

${ }^{47}$ Quoted from Caroline Tisdall, Art into Society, Society into Art (London: ICA, 1974), 48. (Capitals in original.) 
Platschek suggests that it is this pseudo-profound sacralisation of their everyday lives for which buyers of Beuys' art are willing to pay exorbitantly high prices. ${ }^{48}$ Equally disparaging were comments such as the following: "Beuys's character and footstep in the European art world were writ large; indeed one might perceive a certain narcissistic and grandiose bent." 49 And the same Thomas Mann, who praised Hauptmann's artistic achievement on his $70^{\text {th }}$ birthday, in his novel The Magic Mountain famously exposed and caricatured Hauptmann's vague, irrational naivete in the guise of the incoherent language of the pompous Dutchman, Mijnheer Peeperkorn. But the latter's utterances are not senseless drivel. On the contrary, in The Magic Mountain Peeperkorn is the only one who predicts the war and its gory inhumanity. ${ }^{50}$

Just like Peeperkorn's pre-WWI prophecy in Thomas Mann's novel, Hauptmann's social commitment in his early drama has stood the test of time. Cowan attributes the durability of The Weavers to the fact that this drama presents "a picture of misery in its classical form." "51 We may add that it not only presents a timeless image of misery, but it also deals with very specific problems such as victimisation, the spectre of unemployment, the role of workers' rights, the helplessness of the average person in the face of the 'system' and rapid change, the power of the press to distort and persuade, and the way the rich and/or influential turn a blind eye to the problems of the less fortunate. ${ }^{52}$ As long as such

48 Hans Platschek, Über die Dummheit in der Malerei (Frankfurt: Suhrkamp, 1984), 83-89. See also: Mark Rosenthal, Sean Rainbird and Claudia Schmuckli, Joseph Beuys: Actions, Vitrines, Environments (London: Menil Foundation, 2004), 10: "Throughout his career, Beuys was surrounded by questions and controversy: was he, as one critic derided him, a sham or a shaman?"

${ }^{49}$ Rosenthal, Rainbird and Schmuckli, ibid.

${ }^{50}$ Hofmann (n. 22 above): 149.

51 Roy C. Cowan, Hauptmann Kommentar zum dramatischen Werk (München: Winkler, 1980), 64.

52 A student of The Weavers was struck by the play's relevance to NZ society. It seemed pertinently summed up in the Dominion editorial of 12 June 1991: "The poor should [not] take any comfort that their hardships are being more widely acknowledged. [The way to measure poverty] will be decided by people who are not poor, and [the report] is likely to be so sanitised by sociological jargon that their plight will remain comfortably remote from the rest of society." 
problems exist, the drama will have currency, continuing to be, in Beuys" terms, a shining example of "social sculpture". 